\title{
Journey towards Achieving Excellence
}

\author{
Dr. Nidhi Chadha ${ }^{1 *}$
}

\section{ABSTRACT}

The present paper describes excellence as one of the major concerns in varied domains because it seems to be one of the most effective ways to ensure optimal human functioning. The society in which one grows up determines to a large extent that how we perceive excellence and the goal of getting the best out of our life. Excellence as a concept has seldom been the subject of academic scrutiny. The purpose of this paper is to consider excellence as a multifactorial entity in terms of its components and research fields. Excellence does not urge us to be at the top in every single aspect of life, rather it allows excelling in any particular area of work where we can really make a difference. In essence, excellence is the pathway for success at work, at home and in life in general. It is all about being the best one can be and maximizing our gifts, talents and abilities to perform at our highest potential. Therefore, the promotion of excellence is necessary to determine superior performance of individuals in different fields of knowledge and for understanding the true meaning of life filled with maturity and integrity.

Keywords: Excellence, Focus, Happiness

Throughout our lives, we all strive to get success at work, at home and in life in general. Researchers and professionals over the past few decades in educational, occupational and social domains have paid growing attention to the concept of excellence. As we move towards $21^{\text {st }}$ century, the spur and growth of human potential in terms of excellence emerges as the foremost concern as it seems to be one of the most effective ways to ensure the survival of human beings across the globe.

\section{Conceptualization of Excellence}

The term excellence comes from the Latin word excellentia, which means the quality of being excellent. Excellence refers to the excellent as the one at the highest level, and if it is an individual, someone who achieves something superior, in a position above what was expected, exceeding all expectations, surprising, creating new possibilities in a given field of knowledge.

\footnotetext{
${ }^{1}$ Resource Person,Department of Psychology, Post Graduate Government College, Sector-11, Chandigarh, India *Responding Author (C) 2016 I N Chadha; licensee IJIP. This is an Open Access Research distributed under the terms of the Creative Commons Attribution License (http://creativecommons.org/licenses/by/2.0), which permits unrestricted use, distribution, and reproduction in any Medium, provided the original work is properly cited.
} 
Excellence is all about knowing oneself and one's strengths, taking pride in oneself and showing one's talents.

The Shorter Oxford Dictionary (2002) defined excellence as 'the possession of good qualities or abilities to an eminent or unusual degree'. According to Jerry Flury (2010) excellence is defined as, "possession chiefly of good qualities in an unusual degree; surpassing virtue, merit, worth and value". In essence, excellence is the opposite of perfectionism. Perfectionism is losing one's true self in the demands of society and trying to emulate a person who is not you and whom one can never become. On the other hand, Excellence is to be at the center of one's own universe, and from that grounded position be able to stand out by making use of one's unique talents.

Within the vicinity of psychology, the first generation of research focused on heredity or genetics. At the time, Galton (1869/1979) provided scientific status to the study of giftedness, publishing the first paper on the subject, Hereditary Genius, which emphasized family aspects and the genetic transmission of intellectual and motivational ability. The second generation of research draws closer to addressing excellence that is marked by the observation of personality and other psychological aspects. Cox (1992) estimated the personality scores of one hundred adult individuals considered to be geniuses, confirming that personality traits are complementary to intelligence in the description of high performance levels.

However, research in third generation marked excellence to greater diversity of themes with an emphasis on experience and practice. De Groot (1965/1978) was the first to compare the performance of expert and beginner chess players, attributing expertise to prior knowledge and extensive experience in the field, a concept that was corroborated and further elaborated by Simon and Chase (1973) and was later called "deliberate practice" by Ericsson (2005). A stage that occurred simultaneously with the latter was initiated by Maslow (1954/1970), who also inaugurated the humanist movement in Psychology. Maslow explained that self-actualization motivates growth and to reach this stage the previous needs already have to be met. Rogers (1961/1982) also took a scientific look at what is beautiful and virtuous in the human being whether it is latent or manifest-based on the unique experience of each. He held that all persons are capable of using their latent potential to do what they desire and transform themselves based on a tendency to self-fulfillment consistent with their heredity, self and context.

\section{Recent Theoretical Perspective of Excellence}

In today's noisy fast-moving world, it's easy to become distracted, isolated and overwhelmed. Yet focus is integral to our excellence, happiness, productivity and relationships. There is a shift in interest among psychologists related to the cure of mental diseases to how to make people's lives more productive to finally identification and nurturing of talents.

However, it is with the advent of Positive Psychology movement that led to research on concerning excellence of human performance in most varied domains. Not only this, in the last 
decade, driven by Positive Psychology many studies have been developed seeking to understand the functioning of individuals with superior abilities in the most varied segments of human life. These studies seek to describe the characteristics of excellence and its foundations, as well as to identify the personal and contextual variables of excellence and under what conditions it occurs. Seligman and Csikszentmihalyi (2000) in a special issue on 'Happiness, Excellence, and Optimal Human Functioning', outlined a framework for a new science of Positive Psychology that would more deeply investigate topics such as subjective well-being (Diener, 2000), optimism (Peterson, 2000) and states of excellence (Lubinski \& Benbow, 2000).

Recently, Goleman (2014) proposed that "focus is the hidden driver of excellence". The three areas of focus are (a) inner (self-management), (b) other (empathy for others) and (C) outer (awareness of broad patterns and complex systems). Knowing how to focus on our inner thoughts and feelings, to be present and empathic with other people and to pay attention to larger systems and societal trends are essential components of success today.

Living a life of excellence takes effort, but at the same time is rewarding and gives you energy so that you can keep up your work.

\section{Elements of Excellence}

According to Orlick (2005), these seven basic elements of excellence allow to excel or become the best one can possibly be in one's chosen pursuit. The first two elements are Commitment and Belief. Together they form the hub or heart of human excellence. The five remaining elements of excellence are mental skills that channel commitment and belief into a series of positive actions that make one's performance wheel run smoothly and efficiently. These seven elements penned down below make up the 'Wheel of Excellence' are closely linked and often operate interdependently.

\section{- Commitment}

Commitment is the first essential ingredient guiding the pursuit of excellence. To excel at anything one must have or develop an extremely high level of dedication, self-discipline, passion, joy or love for what one is doing. One must ignite something within that drives to excel. One must not only commit to the goal of excelling, but must also commit to act on a daily basis in ways that lead to excel. It means setting clear personal goals and relentlessly pursuing them.

\section{- Belief/Self-Confidence}

Belief is the second essential ingredient in the pursuit of excellence. Excellence is guided by belief in one's potential, goal, meaningfulness of goal, and trust in one's capacity to reach that goal. Where there is unwavering belief in your capacity to carry out a mission and absolute connection with your performance, doors are opened to higher levels of excellence.

\section{- Full Focus}

Focusing is the single most important mental skill associated with performance excellence. Focusing refers to the ability to concentrate totally on what one is doing, seeing, reading, 
hearing, learning, feeling, observing or experiencing while engaged in an activity or performance. The successful execution of all mental skills on the Wheel of Excellence is dependent upon one's ability to focus appropriately.

\section{- Positive Images}

Positive imagery is useful for guiding belief, focus, and performance, and for creating good feelings about oneself and one's capacity. Through positive imagery one can preexperience and re-experience feelings, sensations, skills or actions that are important for the successful execution of task. High quality images of high quality performances allow to experience following desired courses of action and help to feel ready to perform to one's highest potential.

\section{- Mental Readiness}

Mental readiness refers to a positive state one carry into learning and performance situations. It is dependent upon the other mental skills on the Wheel of Excellence. To have a realistic chance of excelling one must become highly proficient at mentally readying oneself to: learn essential mental, physical and technical skills, practice essential skills to perfection, and effectively perform those skills under competitive conditions.

\section{- Distraction Control}

Distraction control refers to one's ability to maintain or regain a positive, effective focus when faced with potential distractions, negative input, or setbacks. These distractions may be external, arising from environment, or internal, arising from own thinking or expectations. Maintaining and regaining a constructive focus is a critical part of performing to one's capacity on a consistent basis, whether distractions occur before, during, between or after events.

\section{- Constructive Evaluation}

Constructive evaluation includes looking for the good things and targeting areas for improvement in oneself, one's performance, one's environment and one's experiences. One can draw inspiration, confidence and joy from reflecting on positive experiences and personal highlights.

\section{Excellence and its Research Fields}

In an attempt to organize studies addressing excellence, Araujo, Cruz \& Almeida (2007) highlighted three fields of research in excellence:

The first approach emphasizes on superior abilities, which associates excellence with talent and above average skills. It is known that excellence expresses a high level of intelligence, a more rapid or early development of brain functions, and is influenced by genetic, psychological, social, cultural and educational factors (Gagné, 2004, 2007).

Second approach concerns with expertise, to evaluate high performance in certain domains. Expertise in excellence is the result of the investment individuals make in fields concerning which they have knowledge and feel very competent, and the result of the ability to transform 
weaknesses in other domains (different from the domain in which they are expert) in aspects that are irrelevant to their performance.

The third approach focuses on wisdom as a concept that involves maturity, intelligence, and creativity; an exceptional level of human functioning that is related to excellence; a state of spirit and behavior balanced by intellectual, affective, and motivational aspects.

\section{Strategies to achieve Excellence}

Shmerling (2013) propounded the following ways to achieve excellence and are given below:

\section{- Pursue professional and personal development}

Work to learn the knowledge and skills. This is an ongoing lifelong process. One will constantly be developing and growing, and be open to new ideas and possibilities. It refines thinking process, and enables 'higher' level thinking and analysis. Personal development enables to be the best person one can be with traits that will assist to move forward. It develops one's attributes and instil self discipline.

\section{- Have a mentor or coach}

A mentor or coach has experience and wisdom to see a broad perspective and see things that we may not be able to see. The role of a mentor or coach is to guide to achieve excellence and success.

\section{- Believe in yourself}

Self-belief is paramount to success. One need to first believe in oneself to reach one's goal. Also, one need to have self-confidence for others to believe in you. At times, we all lack confidence. Work on self talk and confidence to get back on track. Confidence grows as we begin to see results, and over time.

\section{- Have a plan}

Every goal needs a plan to make it come to life, otherwise it's a dream. Plan is the roadmap - strategy to get to where one want to go.

\section{- Be creative on how to achieve your goal}

Think creatively and laterally - outside the square. Open yourself to possibilities to try something new. The old tried way of achieving will only give you average success. Open yourself to new possibilities and the creativity will flow. This is fundamental to your success.

\section{- Work hard and manage your time strategically}

Don't just work hard, also work smart on the right things. Break your tasks into a manageable size so it's easier to tackle. These tasks form part of a whole. Eventually, you'll achieve your goal. Employing such strategies is the only way to achieve results.

\section{- Be adaptable}

Adaptability is one of the essential pillars of excellence. As you may already know, change is inevitable - You can either cower in the face of change, learn to deal with it or even turn it into your favor. Be ready for change at all times and develop a friendly relationship with change. 


\section{- Never give up}

Don't ever give up. Remember that defeat never occurs unless you accept it as defeat. If a certain problem is too big for you to handle, break it down into smaller pieces so it's easier for you to tackle them. As long as you keep trying, you will eventually achieve your goal.

\section{- Enjoy what you are doing and find your passion}

By focusing on what you enjoy doing, and the things that come easy to you, you'll become the best 'you' possible.

\section{CONCLUSION}

It is worthy to mention here that positive psychology has led to research new topics, instigated new approaches, and stimulated new ways of thinking about existing constructs. Further, an intriguing fact of the present paper posits that, it is our positive thinking which paves way towards excellence. It forms the basis of a set of personal development techniques known as 'Neuro Linguistic Programming' which provides both an art and science of how individuals top or excel in different fields of life. Therefore, it can also be said as 'the new science of personal achievement', 'the psychology of achievement' and 'the psychology of excellence'.

\section{REFERENCES}

Araújo, L. S., Cruz, J. F. A., \& Almeida, L. S. (2007). Excelência humana: Teorias explicativas e papel determinante do professor. Psicologia, Educação e Cultura, 11(2), 197-221.

Cox, C. M. (1992). The early mental traits of 300 geniuses. In R. S. Albert (Ed.), Genius \& eminence (2nd ed., pp. 53-58). Oxford, England: Pergamon. (Original publicado em 1926)

De Groot, A. D. (1978). Thought and choice in chess (2nd ed.). The Hague: Mouton. (Original publicado em 1965)

Diener, E. (2000). Subjective well-being: The science of happiness and a proposal for a national index. American Psychologist, 55(1), 34-43. doi: 10.1037/0003-066X.55.1.34

Ericsson, K. A. (2005). Recent advances in expertise research: A commentary on the contributions to the special issue. Applied Cognitive Psychology, 19(2), 233-241. doi:10.1002/acp.1111

Flury, J. (2010). Pursuing Excellence. www.sermoncentral.com/.../pursuing-excellence-jerryflury-sermon-on-c

Gagné, F. (2004). Transforming gifts into talents: the DMGT as a developmental theory. High Ability Studies, 15(2), 119-147. doi:10.1080/1359813042000314682

Gagné, F. (2007). Ten commandments for academic talent development. Gifted Child Quarterly, 51(2), 93-118. doi:10.1177/0016986206296660

Galton, F. (1979). Hereditary genius: An inquiry into its laws and consequences. London, England: Julian Friedman. (Original publicado em 1869)

Golemen, D. (2014). Focus: The Hidden Driver of Excellence. Harper. ISBN 0062114867

Lubinski, D., \& Benbow, C. P. (2000). States of excellence. American Psychologist, 55(1), 137150. doi: 10.1037/0003-066X.55.1.137 
Maslow, A. H. (1970). Motivation and personality (2nd ed.). New York: Harper \& Row. (Original publicado em 1954)

Orlick, T. (2005). The wheel of excellence. Zone of Excellence www.zoneofexcellence.ca/free/wheel.html

Peterson, C. (2000). The future of optimism. American Psychologist, 55(1), 44-55. doi: 10.1037/0003-066X.55.1.44

Rogers, C. R. (1982). Tornar-se pessoa (M. J. C. Ferreira, Trad.). São Paulo: Martins Fontes. (Original publicado em 1961)

Seligman, M. E. P., \& Csikszentmihalyi, M. (2000). Positive psychology: An introduction. American Psychologist, 55(1), 5-14. doi:10.1037/0003-066X.55.1.5

Shmerling, L. (2013). 11 Tips to Achieve Excellence: The Range Between Best and Average. www.abn.org.au > Resource Centre > Articles

Simon, H. A., \& Chase, W. G. (1973). Skill in chess. American Scientist, 61(4), 394403. 